\title{
Implementation of Entrepreneurship Education in Forming The Character of Entrepreneurship at Muhammadiyah Kebumen Elementary School
}

\author{
Syifa Lailatul Mutmainnah, Nurlia Agustin, Widia Indra Kartika, Moh.Salimi
}

Universitas Sebelas Maret

syifalaila2907@gmail.com

\section{Article History}

accepted 24/09/2019

\begin{abstract}
This study aims to determine the entrepreneurship education strategy carried out by schools in shaping entrepreneurial character at SD Muhammadiyah Kebumen in order to be able to help students gain knowledge about entrepreneurship from an early age. This research is a qualitative descriptive study conducted at SD Muhammadiyah Kebumen. Data collection methods used, namely observation, interviews, and questionnaires. The results of this study indicate: (1) educational strategies at SD Muhammadiyah Kebumen in the formation of entrepreneurial character through entrepreneurship education integrated with learning, namely Preparing educators with entrepreneurial spirit through Market Day activities, Extracurricular Entrepreneurship, and Entrepreneurship Exhibitions and the formation of Entrepreneurial Educators. Entrepreneurship by Developing learning tools, Providing Continuing Entrepreneurship Education and Training for Educators, and Appreciation; (2) the results of the formation of entrepreneurial character through entrepreneurship education stated that the honesty aspect reached $81 \%$, the self-confidence aspect reached $85 \%$, the competitive aspect was $81 \%$, the creative aspect was $83 \%$, the aspect of future orientation was $80 \%$ and the aspect of orientation was $77 \%$
\end{abstract}

Keywords: Entrepreneurship Education, Entrepreneurship Character, Elementary School

\begin{abstract}
Abstrak
Penelitian ini bertujuan untuk mengetahui strategi pendidikan kewirausahaan yang dilakukan oleh sekolah dalam membentuk karakter kewirausahaan di SD Muhammadiyah Kebumen agar mampu membantu peserta didik mendapatkan pengetahuan tentang kewirausahaan sejak dini. Penelitian ini merupakan penelitian deskriptif kualitatif yang dilakukan di SD Muhammadiyah Kebumen. Metode pengumpulan data yang digunakan, yaitu observasi, wawancara, dan angket. Hasil penelitian ini menunjukkan: (1) strategi pendidikan di sd muhammadiyah kebumen dalam pembentukan karakter kewirausahaan melalui pendidikan kewirausahaan yang terintegrasi dengan pembelajaran yaitu mempersiapkan tenaga terdidik yang berjiwa kewirausahaan dengan melalui kegitan market day, ekstrakulikuler kewirausahaan, dan pameran kewirausahaan serta pembentukan tenaga pendidik yang berjiwa kewirausahaan dengan mengembangkan perangkat pembelajaran, memberikan pendidikan dan pelatihan kewirausahaan yang berkesinambungan bagi tenaga pendidik, dan penghargaan; (2) hasil pembentukan karakter kewirausahaan melalui pendidikan kewirausahaan menyatakan bahwa pada aspek kejujuran mencapai $81 \%$, aspek percaya diri mencapai $85 \%$, aspek kompetitif $81 \%$, aspek kreatif $83 \%$, aspek berorentasi pada masa depan $80 \%$ dan aspek berorentasi pada hasil $77 \%$.
\end{abstract}

Kata Kunci: Pendidikan Kewirausahaan, Karakter Kewirausahaan, Sekolah Dasar

Social, Humanities, and Education Studies (SHEs): Conference Series https://jurnal.uns.ac.id/shes

p-ISSN 2620-9284

e-ISSN 2620-9292 


\section{PENDAHULUAN}

Undang-Undang No. 20 Tahun 2003 Tentang Sistem Pendidikan Nasional Pasal 3 , menyatakan bahwa pendidikan nasional berfungsi mengembangkan kemampuan dan membentuk watak serta peradaban bangsa yang bermartabat dalam rangka mencerdaskan kehidupan bangsa, bertujuan untuk mengembangkan potensi peserta didik agar menjadi manusia yang beriman dan bertakwa kepada Tuhan Yang Maha Esa, berakhlak mulia, sehat, berilmu, cakap, kreatif, mandiri, dan menjadi warga negara yang demokratis serta bertanggung jawab. Berkaitan dengan ketercapaian tujuan pendidikan nasional terutama yang mengarah pada pembentukan karakter yang terkait dengan pembentukan sikap dan perilaku wirausaha peserta didik, maka untuk mensukseskan tujuan pendidikan nasional tersebut perlu adanya pendidikan kewirausahaan untuk membentuk karakter wirausaha pada peserta didik.

Pentingnya peran kewirausahaan bagi kegiatan ekonomi baik di negara maju maupun negara berkembang, wirausaha mampu menjadi pendorong perekonomian dan juga menciptakan lapangan pekerjaan. Menurut Mc. Clelland bahwa proporsi yang wajar jumlah wirausaha di suatu negara minimal $2 \%$ dari jumlah penduduk (Sugeng, 2016). Pada tahun 2017 rasio wirausaha di Tanah Air telah mencapai 3,1\% (bps.go.id) dari total jumlah penduduk yang saat ini sekitar 260 juta jiwa. Dengan banyaknya jumlah wirausaha maka produk-produk yang akan dihasilkan akan semakin banyak dan berbanding lurus dengan jumlah lapangan pekerjaaan. Permasalahannya, kondisi ketenagakerjaan di Indonesia sekarang ini belum bisa dikatakan dalam kondisi yang membaik sehingga perlu meningkatkan sumber daya manusia melalui pendidikan yang salah satunya adalah pendidikan kewirausahaan.

Menurut Astiti (2014: 43) pendidikan kewirausahaan merupakan upaya menginternalisasikan jiwa dan mental kewirausahaan melalui institusi pendidikan. Sedangkan Menurut Permatasari (2016: 6) Pendidikan kewirausahaan merupakan salah satu bentuk aplikasi kepedulian dunia pendidikan terhadap kemajuan bangsanya. Berdasarkan pendapat tersebut, dapat diketahui bahwa pendidikan kewirausahaan merupakan upaya yang dilakukan oleh lembaga pendidikan untuk menanamkan pengetahuan, nilai-nilai, jiwa, dan sikap kewirausahaan kepada peserta didik dengan tujuan untuk mengembangkan sikap, jiwa dan kemampuan menciptakan sesuatu yang bernilai bagi diri sendiri maupun orang lain serta kemajuan negara.

Menurut Birgthistle, et al, 2007 bahwa salah satu cara dalam peningkatan kualitas sumber daya manusia adalah dengan pemberlakuan model pendidikan Life Skill Education atau pendidikan kecakapan hidup (Sugeng, 2016). Sejalan dengan itu menurut Wicaksono dan Rachmadyanti (2015: 421) pendidikan kewirausahaan adalah pendidikan yang menerapkan prinsip- prinsip dan metodologi kearah pembentukan kecakapan hidup (life skill) pada siswa melalui kurikulum yang dikembangkan di sekolah. Dalam menyikapi hal tersebut orang tua dan guru dalam mendidik anak dizama sekarang tidak bisa disamakan dengan mendidik anak zaman dahulu. Dibutuhkan kreatifitas dan inovatif dalam mendidik anak di zaman sekarang. Pada usia emas yang memiliki potensi yang luat biasa terutama kinerja otaknya, anak-anak harus diajarkan entrepreneur sejak dini, agar dimasa depan generasi tersebut tidak lagi menjadi bangsa kuli, tetapi menjadi bangsa bos. (Nuseto, 2010)

Dalam membentuk kecakapan hidup bagi pesera didik terdapat strategi bagi embaga pendidikan yang diakukan dalam membentuk jiwa kewirausahaan yang dimilikinya. Menurut Kusuma (2017: 81), terdapat beberapa strategi bagi sekoah dasar untuk menumbuhkan jiwa kewirausahaan di lingkungannya, yaitu: 1) Mempersiapkan tenaga terdidik yang berjiwa kewirausahaan yaitu (a) Melakukan kegiatan Market Week di sekolah, (b) Kegiatan Field Trip ke Pasar Tradisional dan Pasar Modern, (c) Pengadaan Ekskul Kewirausahaan, (d) Pengadaan Laboratorium Kewirausahaan, (e) Penataan Suasana Sekolah Berbasis Kewirausahaan, dan (f) Penghargaan. Memiliki Tenaga Pendidik yang Berjiwa Kewirausahaan yaitu (a) Mengembangkan perangkat 
pembelajaran, (b) Memberikan Pendidikan dan Pelatihan Kewirausahaan yang Berkesinambungan bagi Tenaga Pendidik, dan (c) Penghargaan

Geoffrey G. Meredith dalam Suharyadi, dkk (2007: 9) mengemukakan tentang ciri- ciri kewirausahaan, yaitu sebgai berikut. (1) Percaya diri, (2) Berorientasi Tugas dan Hasil, (3) Berani mengambil resiko, (4) Kepemimpinan, (5) Keorisinilan, (6) Berorientasi Masa Depan. Sedangkan ciri-ciri dan watak kewirausahaan menurut Meredith untuk lebih jelasnya terdapat dalam tabel dibawah ini:

Tabel 1. Tabel ciri dan watak kewirausahaan menurut Geoffrey G. Meredith

\begin{tabular}{lll}
\hline \multicolumn{1}{c}{ Cir-ciri } & \multicolumn{1}{c}{ Watak } \\
\hline Percaya Diri & $\begin{array}{l}\text { Keyakinan, tidak tergantung, individualisme, dan } \\
\text { optimisme }\end{array}$ \\
Berorientasi Tugas dan & $\begin{array}{l}\text { Kebutuhan untuk berprestasi, ketekunan dan } \\
\text { ketabahan, kerja keras, moti } \\
\text { vasi, energik, dan inisiatif }\end{array}$ \\
Berani Mengambil Resiko & $\begin{array}{l}\text { Kemampuan untuk menagmbil resiko yang wajar dan } \\
\text { suka tantangan }\end{array}$ \\
Kepemimpinan & $\begin{array}{l}\text { Perilaku sebagai pemimpin, luwes bergaul dengan } \\
\text { orang lain, menerima/menanggapi saran dan kritik }\end{array}$ \\
Keorisinilan & $\begin{array}{l}\text { Inovatif, kreatif dan fleksibel } \\
\text { Berorientasi Masa Depan } \\
\text { Memiliki prespektif dan pandangan ke depan }\end{array}$
\end{tabular}

Dengan demikian, melalui pendidikan kewirausahaan mampu merubah pola pikir serta membentuk karakter wirausaha peserta didik yang mandiri dan tidak berorientasi menjadi pencari kerja melainkan pembuka lapangan kerja, karena dengan usia antara 7-12 tahun pemikiran peserta didik sekolah dasar dapat dibentuk dengan kebutuhan lingkungan, sehingga pola pikir tentang cita-cita anak menjadi wirausahawan harus segera dibentuk. Berdasarkan beberapa uraian di atas, menunjukkan bahwa pembelajaran kewirausahaan dapat menjadi salah satu alternatif penanaman jiwa kewirausahaan.

Nilai-nilai kewirausahaaan dalam masa krisis seperti saat ini dirasa sangat penting terutama dilakukan pada wilayah dunia pendidikan khususnya dikalangan peserta didik sekolah dasar. Implementasi pendidikan kewirausahaan dalam membentuk karakter kewirausahaan di SD Muhammadiyah Kebumen merupakan langkah konkrit dalam menganti sipasi dan mempersiapkan generasi muda yang mempunyai jiwa wirausahaa dalam menghadapi persaingan globalisasi saat ini. Atas dasar itulah, menarik untuk diteliti tentang strategi serta hasil pembentukan karakter kewirausahaan di SD Muhammadiyah Kebumen melalui pendidikan kewirausahaan.

\section{METODE}

Metode yang digunakan dalam penelitian ini merupakan metode penelitian deskriptif. Metode penelitian diskriptif adalah penelitian yang bermaksud memahami fenomena tentang apa yang dialami oleh subjek penelitian secara holistik dan dengan cara diskripsi dalam bentuk kata-kata dan bahasa pada suatu konteks alamiah dan dengan memanfaatkan berbagai metode alamiah (Moleong, 2010). Penelitian ini dilakukan untuk memperoleh gambaran mengenai pelaksanaan program pendidikan kewirausahaan dalam pembentukan karakter kewirausahaan di SD Muhmmadiyah Kebumen. Instrumen penelitian ini terdiri dari wawancara dan angket. Subjek penelitian ini adalah kepala sekolah, guru ekstrakulikuler kewirausahaan, dan peserta didik kelas 5 sebanyak 43. Teknis analisis data pada penelitian ini adalah dengan menggunakan analisis diskritif, data dan informasi yang didaptkan didikripsikan secara kualitatif. Data yang diperoleh dijelaskan secara deskriptif. Adapun teknik analisis data mengenai pembentukan karakter kewirausahan dan menggunakan rumus peresentase menurut Purwanto (2013: 102) berikut ini: 


$$
\text { NP }: \frac{R}{S M} \times 100
$$

Keterangan:

$\begin{array}{ll}\text { NP } & \text { : Nilai persen yang dicari tau diharapkan } \\ \text { R } & \text { : Skor mentah yang diperoleh } \\ \text { SM } & \text { : SM maksimum ideal dari tes yang bersangkutan } \\ 100 & \text { : Bilangan tetap }\end{array}$

HASIL DAN PEMBAHASAN

Penelitian dilaksanakan pada tanggal 12 September 2019 di ruang kepala sekolah untuk melakukan wawancara kepada kepala sekolah dan bidang kesiswaan. Sedangkan pada tanggal 16 September 2019 di kelas V dilakukan penelitian angket. Berdasarkan wawancara dan angket pembentukan karakter kewirausahan melalui pendidikan kewirausahaan memperoleh hasil sebagai berikut:

\section{A. Strategi Pendidikan Di SD Muhammadiyah Kebumen Dalam Pembentukan Karakter Kewirausahaan Melalui Pendidikan Kewirausahaan}

Berdasarkan hasil wawancara diperoleh informasi bahwa SD Muhammadiyah Kebumen telah melaksanakan strategi pendidikan kewirausahaan berupa:

1. Mempersiapkan tenaga terdidik yang berjiwa kewirausahaan yaitu:

a. Market Day

Market day yang berada di SD Muhammadiyah Kebumen adalah sebuah kegiatan rutinan yang dilakukan satu semester sekali pada saat setelah PTS dan PAS. Yang terlibat dalam kegiatan market day adalah semua kelas, kelas 4 sampai kelas 6 biasanya menjadi penjual dan kelas 1 sampai kelas 3 menjadi pembeli. Produk yang dijual belikan dalam kegiatan market day adalah hasil karya peserta didik baik berupa kerajinan dari bahan dasar setengah jadi maupun bahan dasar belum jadi. Produk yang dibuat juga bisa berupa olahan makan seperti makanan tradisonal. Peran pendidik dalam kegiatan market day adalah sebagi fasilitator, motivator serta konsumen sebagai bentuk pengghargaan hasil karya peserta didik. Di SD Muhammadiyah Kebumen terdapat kunjungan ke SD/tempat yang sudah melaksanakan kegiatan market day terlebih dahulu seperti PLUT, SD Saten di Yogyakarta, SD Diponegoro di Semarang. Dalam kegiatan kunjungan tersebut ada kegiatan yang inovatif kemudian diterapkan di SD Muhammadiyah kebumen seperti kegiatan kerajian anyaman dari bambu.

Pelaksanaan market day di SD Muhammadiyah Kebumen seperti halnya dilakukan dalam penelitian yang dilakukan oleh Sulistiyowati (2016) di SDIT Mutiara Hati Malang berbeda dimana program market day dilakukan dengan rutin oleh pihak SDIT Mutiara Hati setiap hari Rabu pada jam istirahat agar tidak mengganggu jam belajar yang sifatnya hanya diikuti oleh peserta didik yang berminat untuk berjualan.

b. Ekstrakulikuler Kewirausahaan

Ekstrakulikuler Kewirausahaan di SD Muhammadiyah Kebumen adalah kegiatan bakat dan minat bagi peserta didik yang dilakukan satu minggu sekali biasanya pada hari Sabtu. Kegiatan yang dilakukan dalam ekstrakulikuler kewirausahan yaitu kerajinan, memasak, dan membatik. Dalam kegiatan memasak biasanya dilakukan didapur sekolah dimana fasilitas sudah tersedia dari sekolah. Sedangkan kegiatan membatik dan kerajianan dilakukan dilapangan sekolah. Setiap kelompok terdapat guru pembimbing dalam membatu peserta didik untuk mengarahkan selama kegiatan.

\section{c. Laboratorium Kewirausahaan}

Laboratorium Kewirausahaan di SD Muhammadiyah Kebumen belum tersedia, tetapi terdapat tempat untuk menyimpan hasil karya, kerajinan peserta didik dalam bentuk etalase yang diletakan di perpustakaan dan dikelas. Etalase ini bertujuan untuk memamerkan dan memajang hasil karya dan kerajinan peserta didik. 


\section{d. Pameran Kewirausahaan}

Pameran Kewirausahaan adalah kegiatan untuk memamerkan hasil karya dan kerajinan peserta didik. Dalam kegitan ini SD Muhammadiyah Kebumen mengundang salah satu stasiun televisi di kebumen yaitu RatihTV untuk meliput kegiatan pameran di SD Muhammadiyah Kebumen. Karya dan kerajinan yang dipamerkan merupakan hasil karya peserta didik baik individu maupun kelompok dimana karya dan kerajinan tersebut mempunyai nama dagang (merk) serta harga jual sendiri. Beberapa karya dan kerajinan merupakan hasil karya dan kerajinan yang pernah diikutsertakan dalam perlombaan.

\section{Tenaga Pendidik yang Berjiwa Kewirausahaan}

a. Mengembangkan perangkat pembelajaran

Pada SD Muhammadiyah Kebumen dalam mengembangkan perangkat pembelajaran disesuaikan dengan RPP yang dibuat pendidik dimana pendidikan kewirausahaan terintegrasi dengan mata pelajaran yang lainnya. Dalam setiap pembelajaran yang terdapat mata pelajaran kewirausahaan guru selalu menyiapkan praktek kewirausahaan yang di kerjakan oleh peserta didik.

\section{b. Memberikan Pendidikan dan Pelatihan}

Berkesinambungan bagi Tenaga Pendidik

Pada SD Muhammadiyah Kebumen terdapat pendidik yang khusus menangani bidang kewirausahaan dari bidang kesiswaan. Pendidik pada SD Muhammadiyah Kebumen juga pernah mengikuti seminar kewirausahaan serta melakukan studi eksplorasi di lapangan seperti kunjungan Pusat Layanan Usaha Terpadu Koperasi Usaha Mikro Kecil dan Menengah (PLUT-KUMKM). Di sekolah ini juga mendatangkan pelatih khusus untuk membekali pendidik dan peserta didik dalam bidang kewirausahaan seperti pengrajin batik.

\section{c. Penghargaan}

Penghargaan tidak hanya untuk peserta didik yang berhasil mengikuti kejuaraan kewirausahaan, akan tetapi para pendidik yang berhasil membuat inovasi ataupun membantu peserta didik dalam kejuaraan kewirausahaan juga mendapatkan penghargaan/apresiasi dari pihak SD Muhammadiyah Kebumen.

Pelaksanaan strategi pendidikan kewirausahaan di SD Muhammadiyah Kebumen yang telah kami lakukan, belum semua terlaksana seperti strategi pendidikan kewirausahaan yang dikemukakan oleh Kusuma (2017: 81). Namun, bahwasannya strategi Pendidikan yang dilakukan dalam pembentukan karakter kewirausahaan melalui Pendidikan kewirausahaan sudah baik dan berjalan dengan semestinya, ditunjukkan dengan mempersiapkan semua komponen yang terlibat bukan hanya peserta didik melainkan tenaga pendidik pun terlibat langsung dalam pembentukan karakter kewirausahaan tersebut. Hal ini juga sejalan dengan hasil penelitian dari Waluyo (2016) tentang penanaman nilai-nilai kewirausahaan di SDN Model Kota Malang yang menyatakan bahwa strategi Pendidikan kewirausahaan yang dilakukan di sekolah dasar dapat dilakukan dengan ekstrakurikuler, pengintegrasian ke dalam setiap materi pembelajaran, pengembangan diri, dan muatan lokal.

\section{B. Hasil Pembentukan Karakter Kewirausahaan Melalui Pendidikan \\ Kewirausahaan}

Dari hasil penelitian melalui angket yang diberikan kepada peserta didik SD Muhammadiyah Kebumen diperoleh data yang menyatakan bahwa pembentukan karakter kewirausahaan. Berikut ini adalah hasil presentasenya: 
Tabel 2. Hasil Presentase Pembentukan Karakter Kewirausahaan Melalui Pendidikan Kewirausahaan

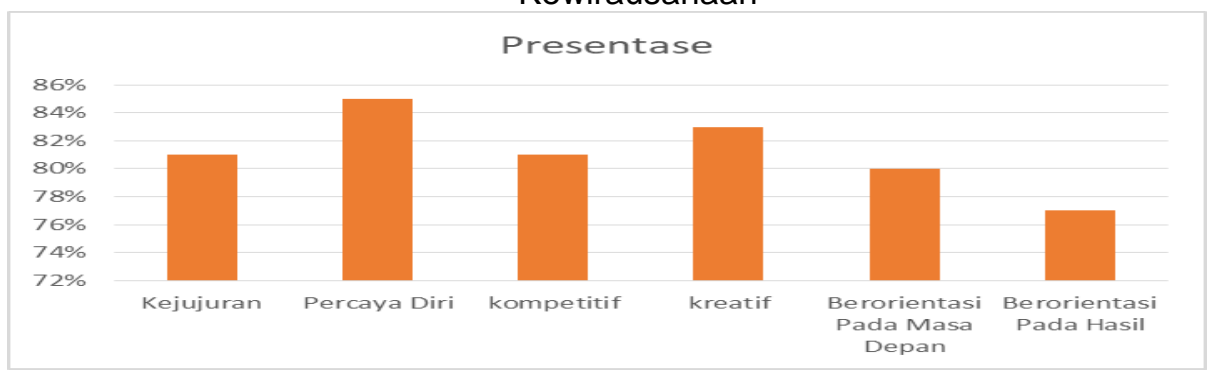

\section{Kejujuran}

Di SD Muhammadiyah Kebumen tingkat presentasi kejujuran dalam karakter kewirausahaan sebesar $81 \%$. Dimana karakter kejujuran berdasarkan hasil wawancara yang telah dilakukan yakni melalui jual beli yang mana pembeli membayar dan mengambil kembalian secara sendiri.

\section{Percaya diri}

Di SD Muhammadiyah Kebumen tingkat presentasi percaya diri dalam karakter kewirausahaan sebesar $85 \%$. Dimana karakter percaya diri berdasarkan hasil wawancara yang telah dilakukan yakni peserta didik tidak malu dalam berjualan. Pada saat berjualan dan dagangannya tidak habis peserta didik tidak malu untuk menawarkan daganganya dengan berkeliling sampai habis.

\section{Kompetitif}

Di SD Muhammadiyah Kebumen tingkat presentasi kompotitif dalam karakter kewirausahaan sebesar $81 \%$. Dimana karakter kompotitif berdasarkan hasil wawancara yang telah dilakukan yakni antar peserta didik saling berlomba-lomba secara sportif agar dagangan yang dijualkan bisa laku habis.

\section{Kreatif}

Di SD Muhammadiyah Kebumen tingkat presentasi kreatif dalam karakter kewirausahaan sebesar 83\%. Dimana karakter kreatif berdasarkan hasil wawancara yang telah dilakukan yakni melalui hasil karya dan kerajinan yang dihasilakn peserta didik dengan melakukan pedoman sekolah yaitu amati-tirucoba-modifikasi. Hal ini juga bisa dilihat dengan hasil karya peserta didik yang bisa memanfaatkan barang-barang disekitar menjadi hasil karya.

\section{Berorientasi masa depan}

Di SD Muhammadiyah Kebumen tingkat presentasi berorientasi masa depan dalam karakter kewirausahaan sebesar $80 \%$. Dimana karakter berorientasi masa depan berdasarkan hasil wawancara yang telah dilakukan yakni ketika peserta didik mendapatkan keuntungan dari hasil penjualannya, uang tersebut digunakan untuk menabung dan kepentingan yang penting.

\section{Berorientasi pada hasil}

Di SD Muhammadiyah Kebumen tingkat presentasi berorientasi pada hasil dalam karakter kewirausahaan sebesar $77 \%$. Dimana karakter berorientasi pada hasil, berdasarkan hasil wawancara yang telah dilakukan yakni ketika peserta didik dalam berjualan berkeinginan untuk mendapatkan keuntungan. Dan yang awal sebuah ekstrakulikuler menjadikan setiap hari berjualan dikarenakan keuntungan yang diperoleh.

Berdasarkan penelitian yang kami lakukan telah sesuai dengan teori yang dikemukaan Geoffrey G. Meredith dalam Suharyadi, dkk (2007: 9) tentang ciri- ciri kewirausahaan, dimana di SD Muhammadiyah Kebumen telah muncul semua karakter-karakter kewirausahaan yang ditumbuhkan dalam pendidikan kewirausahaan di SD Muhammadiyah Kebumen. Selain itu, ciri-ciri karakter kewirausahaan yang ada di sekolah tersebut sejalan dengan penelitian yang dilakukan oleh Sulistiyowati (2016) 
di SDIT Mutiara Hati Malang melalui strategi pendidikan kewirausahaan market day ciri karakteristik kewirausahaan pada peserta didik akan dibentuk dan tumbuh sejak dini seperti percaya diri, berani mengambil resiko, berorientasi pada hasil, dan jujur.

\section{SIMPULAN}

Berdasarkan hasil penelitian yang dilakukan dapat disimpulkan bahwa strategi pendidikan di sd muhammadiyah kebumen dalam pembentukan karakter kewirausahaan melalui pendidikan kewirausahaan menghasilkan : (1) strategi pendidikan di SD Muhammadiyah Kebumen dalam pembentukan karakter kewirausahaan melalui pendidikan kewirausahaan yang terintegrasi dengan pembelajaran yaitu Mempersiapkan tenaga terdidik yang berjiwa kewirausahaan dengan melalui kegitan Market Day, Ekstrakulikuler Kewirausahaan, dan Pameran Kewirausahaan serta pembentukan Tenaga Pendidik yang Berjiwa Kewirausahaan dengan Mengembangkan perangkat pembelajaran, Memberikan Pendidikan dan Pelatihan Kewirausahaan yang Berkesinambungan bagi Tenaga Pendidik, dan Penghargaan; (2) hasil pembentukan karakter kewirausahaan melalui pendidikan kewirausahaan menyatakan bahwa pada aspek kejujuran mencapai $81 \%$, aspek percaya diri mencapai $85 \%$, aspek kompetitif $81 \%$, aspek kreatif $83 \%$, aspek berorentasi pada masa depan $80 \%$, dan aspek berorentasi pada hasil $77 \%$.

\section{DAFTAR PUSTAKA}

Adji, W. S. (2016). Penanaman Nilai-Nilai Kewirausahaan (Studi Kasus di Sekolah Dasar Negeri Model Kota Malang). Jurnal Tarbiyah Vol 5 No 2 Juli - Desember hal 79-95. UIN Malik Ibrahim Malang. Jawa Timur.

Astiti, Y. W. (2016). Pengaruh Pendidikan Kewirausahaan Terhadap Motivasi Berwirausaha dan Keterampilan Berwirausaha Mahasiswa Pendidikan Ekonomi Universitas Negeri Yogyakarta. Skripsi Sarjana Fakultas Ekonomi Universitas Negeri Yogyakarta, Yogyakarta.

Kusuma, A. I. (2017). Strategi Manajemen Sekolah Dasar Dalam Menumbuhkan Jiwa Kewirausahaan. Jurnal JPSD Vol 4 No 1 hal 81. STKIP Muhammadiyah Bangka Belitung.

Moleong, Lexy. (2010). Metodelogi Penelitian Kualitatif. Bandung; PT. Remaja Rosdakarya

Nurseto, Tejo. (2010). Pendidikan berbasis entrepreneur. Jurnal Pendidikan Akuntasi Indonesia, Vol. VIII. No. 2, 52-59.

Permatasari, A. (2016). Pengaruh Pendidikan Kewirausahaan dan Efikasi Diri Terhadap Minat Berwirausaha Mahasiswa UIN Syarif Hidayatullah. Skripsi Sarjana Fakultas IImu Tarbiyah dan Keguruan UIN Syarif Hidayatullah, Jakarta.

Purwanto, Ngalim. (2013). Prinsip-prinsip dan Teknik Evaluasi Pembeljaran. Bandung; PT Remaja Rosdakarya

Sulistiyowati, P., dan Salwa. (2016) Upaya Mengembangkan Karakter Jiwa Kewirausahaan Pada Siswa Sejak dini melalui program Market Day (Kajian Pada SDIT Mutiara Hati Malang). Jurnal pancaran Vol. 5 No.3 Hal 111-120

Sugeng, B., dkk. (2016). Pengaruh Pendidikan Kewirausahaan di Lingkungan Keluarga, Pembelajaran Kewirausahaan di Sekolah, serta Achievment Motive Terhadap Minat Kewirausahaan Siswa SMA. Jurnal Pendidikan Vol 1 No $11 \mathrm{Hal}$ 2226-2229. Universitas Negeri Malang. Jawa Timur.

Suharyadi, dkk. (2007). Kewirausahaan Membangun Usaha Sukses Sejak Usia Muda. Jakarta: Salemba Empat.

Wicaksono, V. D., dan Rachmadyanti, P. (2015). Pendidikan Kewirausahaan Bagi Anak Usia Sekolah Dasar. Prosiding Seminar Nasional Inovasi Pendidikan Pembelajaran Berbasis Karakter dalam Menghadapi Masyarakat Ekonomi ASEAN. 